\title{
PERSPECTIVES FOR FURTHER RESEARCH
}

From the "Indian issue" of colonial times to the "foreigners within" of the rise of nationalism in the African States, the destiny of the Indian diaspora in East Africa has seen both recurring and specific situations. All the articles presented here conclude that it is necessary to study sources that have hitherto been little or unexploited, and insist on the need to look beyond national borders when studying the Indians of East Africa.

Recognised for the importance of their economic activity in the colonial trading system, the Indians were forced to scale their business down to the regional and than State level. It was only towards the end of the 1980s, with new opportunities arising from the opening up of African countries to the market economy, that the Indians were to see a new extension of their business activities on the international scale, and that new waves of migrants from the Indian sub-continent were to come and settle in turn on the eastern coasts of Africa.

\section{Perspectives pour de nouvelles recherches}

De la «question indienne » du temps colonial à celle des « étrangers de l'intérieur » de la montée des nationalismes dans les États africains, la diaspora indienne d'Afrique orientale connaît à la fois des récurrences et des spécificités de destin. Tous les articles présentés débouchent sur la nécessité de travailler des sources insuffisamment ou encore non exploitées et insistent sur le nécessaire décloisonnement transfrontalier des études concernant les Indiens d'Afrique orientale.

Reconnus pour l'importance de leur activité économique dans le système des échanges coloniaux, les Indiens ont été contraints à la régionaliser, puis à la réduire aux frontières étatiques. Ce n'est que vers la fin des années 1980, et dans le cadre des nouvelles opportunités liées à l'ouverture des pays africains à l'économie de marché, que ces Indiens connaîtront un nouveau déploiement de leurs activités à l'échelle internationale et que de nouvelles vagues de migrants du souscontinent indien s'installeront à leur tour sur les côtes orientales d'Afrique.

\section{Perspectivas para mais investigação}

Da «questão indiana » da época colonial à dos «estrangeiros do interior » da emergência dos nacionalismos nos Estados africanos, o destino da diáspora indiana da África oriental conhece recorrências e também especificidades. Todos os artigos apresentados evidenciam a necessidade de se trabalhar fontes insuficientemente ou ainda não exploradas e insistem particularmente na descompartimentação transfronteiriça dos estudos coloniais sobre os indianos da África Oriental.

Reconhecidas pela importância da sua actividade económica no sistema de trocas coloniais, os indianos foram constrangidos a regionaliza-la para em seguida a reduzir às fronteiras dos Estados. Só em finais dos anos 1980, e no quadro das novas oportunidades associadas à abertura dos países africanos à economia de mercado, que estes indianos conhecerão um novo desenvolvimento das suas actividades à escala internacional e que novas vagas de migrantes do subcontinente indiano se instalarão por seu turno nas costas orientais de África. 
$\mathrm{T}$ he articles featured in this issue are the work of historians, sociologists and anthropologists who have sought to ascertain the social history of the Indian diaspora in East Africa during the colonial period. Generally speaking, we should highlight the worth and importance of the authors' concern with bringing the necessary amount of critical analysis to bear on certain major paradigms - e.g. race, religion and the State - at work in the documentary sources they analyse. It is certainly true that in those sources (archives, written press and official documents) the Indian diaspora was more often than not referred to by others. Still, further exploration of the sources available to us nowadays is certainly commendable in itself. In the case of Mozambique, for example, some sources still remain insufficiently explored (such as the PIDE archives currently kept at the National Archives at Torre do Tombo, in Lisbon), while others actually remain virtually unexplored (such as the archives of the French consulate in Mozambique, kept at the Ministry of Foreign Affairs in Paris, on relationships between the Indian communities in Mozambique and Madagascar; or Britain's Public Records, in London, on the claims and reactions of Mozambique's British Indians up until 1947). Analysis of these sources would certainly open up new avenues of research with respect to the ways in which the various colonial powers regarded the Indian diaspora.

Another avenue of research that seems indispensable is the pursuit of further work on oral accounts, insofar as this could certainly contribute to laying down the as yet unwritten history of the multiple fragments that make up Africa's Indian diaspora, both by casting light on its origins in terms of religion and caste, and by formulating the issue at hand in terms of the relationship between belonging to a given lineage, the social and cultural constructions that are built around it and the formation of trade networks in a specific diasporic context.

On the problematic issue of the construction of identity by the various segments of the Indian community (drawing on Indian-ness, African-ness, the adoption of an European culture and the diasporic dimension in piecemeal fashion), the prevalence of one of these dimensions over the others may be considered mostly as a function of the nature of each group in its relationship with African society and with the colonial and post-independence rulers and administrations. On the other hand, it might also be particularly useful to analyse this diaspora's oral accounts in conjunction with those by white, black and mixed-race populations. Such an effort to write down and explore the memory of these events (which would certainly be possible for the period from World War II onwards) would enable us to understand better the relationship with the other that is such an essential part of the history of the social and cultural identities among Indian communities in the colonial period. The stereotypes developed by each group towards each other, and the marital strategies adopted in each context, for example, are two particularly telling and fundamental aspects of the 'ethnic frontier'. Moreover, the way in which the members of the Indian diaspora were reduced to the status of mere economic agents (i.e. regarded simply as an entrepreneurial diaspora) from the perspective of both the Africans and the Europeans, as well as in the usage and representation of that role by the Indian diaspora itself, constitutes an important part of the way in which identities were 'managed' in the colonial and postcolonial contexts. 
The articles featured in the two parts of this issue also constitute an invitation to develop a comparative social and economic history of the Indian diaspora scattered throughout the Portuguese, German, Belgian, British and French colonial worlds, by drawing on available family life-stories going back to the early 20th Century to map out the merchant trajectories and settlement patterns of Indian populations in East and Central Africa. In this particular period, it seems that, on the one hand, these populations pursued their own objectives rather than submitting to any colonial logic and that, on the other hand, the concept of 'border' was more a construct of the colonial empires than an actual reality on the ground. As a consequence, it is important to bring down the walls that separate the avenues of research between the various Indian communities present in each colonial space - never confined to the areas delimited by any given borders -, while nonetheless, acknowledging the specific character of each diaspora's destiny in relation to those spaces.

Religion plays such a central role for all the sub-groups that make up the Indian communities - be they Catholic, Hindu, Sunni or Shia - that one must exercise great caution when drawing on internal sources without a proper understanding of the relevant religious and civilisational context. Hence the suggestion that it might be particularly worthwhile to bring together researchers with a sound practical and scholarly knowledge of Hinduism and African and Asian Islam. In the case of the Muslim Indian communities, the local/regional religious centres were a source of community cohesion that became all the more important once relationships with their homeland - the Gujarat region - became significantly more difficult as a result of the separation of India and Pakistan in 1947. More recently, religious centres not only became the main loci of community cohesion (thereby assuming the role previously played by the original homeland), but also increasingly played a new role as the basis for global interaction in the religious, economic and even marital domains. This is in contrast to the successive diasporic trajectories of the Catholic Goans, who, despite upholding their relationship with the community (by setting up associations based on trade-based castes, building churches and creating community associations), have tended to merge into the urban tissue of their respective host cities and to pursue much more individualized trajectories.

The famous 'Indian issue', as articulated by the various colonial powers, has in the meantime become that of the 'foreigners within', as defined by the post-independence societies, rulers and administrations. This is an issue that is closely related to the emerging debate on the nature of autochthonous belonging and of social and political citizenship, and which calls for further and deeper analysis in the context of both the African societies and the European societies of destination. It is necessary to identify the specific institutions and groups that have given rise to these ostracizing continuities, as well as the specific events that have brought them back to life. Moreover, it is equally indispensable to analyse in greater depth the role of the radical changes in the representations and actions of these actors that came about at the time of independence, as compared to the pre-existent colonial situations.

Yet another avenue of research that is opened up by the research presented in this issue concerns the development of comparative research on the 're-diasporization' of the Indian community in the wake of African independence. For example, those 
diasporas that emerged from the Portuguese-speaking world and which have circulated throughout that same space and elsewhere, and those that emerged from other colonial spaces and can be found in Great Britain and North America. Conversely, Mozambique, Madagascar and Southern Africa have in the past twenty years hosted several new waves of Indian migrants (from India, Pakistan and Bangladesh), who have posed a series of problems to the 'historical' Indo-Africans, both in terms of their modes of cultural, economic and social incorporation into the settled Indian communities and as regards the feeling of insecurity and unease that has taken hold among the middle classes of those settled Indians when faced with the behaviour of some of these new migrants who are associated with an Indo-African elite that is engaged in illegal trafficking activities.

Finally, these conclusions could not be brought to an end without mentioning the recent academic research resulting from the determination of some researchers (including several Indian ones focusing on their own diaspora of origin) to explore the orally-transmitted history of the Indians in East Africa in the research tradition inaugurated by post-colonial studies (which favour their own ways of addressing and representing their history and the issues involved therein over the history that emerges from the archives, the press and the official documents from the colonial and independence periods) and by subaltern studies (which draw on analytical categories and representations that were largely disregarded by the social sciences up until the 1980s, e.g. women and persons on the social, cultural and economic margins of their communities). The additional 'depth and thickness' that these approaches confer on the 'official' history, seen more often than not from outside the Indian communities, contributes to a reading of the past that upholds justice and acknowledges the existence of a historical debt. It is certainly true that, in this effort to represent and write down their recent history, these accounts only rarely - and rather timidly - dwell on the issue of the relationships of the Indian communities vis-à-vis the African populations. Nevertheless, they cast light on the motivations and actual choices felt and made by the various groups of Indians who have lived in Africa, while bearing in mind that this recent past, as represented in their memory, is partially shaped by their current interrogations and positions.

\section{Post modern open societies or different Indian network dynamic?}

A post-modern approach would characterize our societies as open (with increasing flows of capital, people and information), in contrast to the 'closed' and 'territorialized' character of the societies of the past. The case of the Indian networks, however, exhibits a diametrically different dynamic. Depending on the specific colonial setting in which they operated, these networks partially re-oriented their international exchanges (which have been present for several centuries on both sides of the Indian Ocean) towards more local /regional transactions in the late $1800 \mathrm{~s}$ - a reality that remained in place until after the African independences. The historians featured in this issue have provided us with proof of the ancient character of these relationships (in many ways akin to the actual reinterpretation of history suggested by the cases of China and India) and have highlighted their maintenance and expansion during the colonial period. While the European pres- 
ence has challenged their hegemony in the Indian Ocean, it has also acknowledged the importance of their economic activity in the context of the new system of colonial exchange. It was not until Africa opened up to the international markets in the late 1980s that the Indian networks and diasporas, which had settled in Africa or which had migrated from that continent to Europe or America, again redeployed on an international scale.

Paris, July 2007

Joana PEREIRA LEITE

Universidade Técnica de Lisboa

Instituto Superior de Economia e Gestão

Nicole KHOURI

Université Paris I Panthéon-Sorbonne

Centre d'études des mondes africains 


\title{
REVUE TIERS MONDE
}

Revue Tiers Monde, $\mathrm{n}^{\circ}$ 192, octobre-décembre 2007

\author{
Revue trimestrielle publiée par \\ l'Institut d'Étude du Développement Économique et Social \\ Université de Paris I Panthéon-Sorbonne
}

\section{LE FINANCEMENT DU DÉVELOPPEMENT \\ Sous la direction d'Éric Berr}

Éric BERR

Philippe HUGON

Éric BERR,

François COMBARNOUS

Lisa CHAUVET,

Sandrine MESPLÉ-SOMPS

Jacques POIROT

André MEUNIÉ,

Béatrice QUENAULT

$\underline{\text { Varia }}$

Désiré AVOM

Catherine FIGUIÈRE, Laëtitia GUILHOT

Bertrand BELLON, Adel BEN YOUSSEF, Hatem M'HENNI
Introduction

Rentabilité du secteur bancaire et défaillances du financement du développement. Le cas de la CEMAC

Une autre lecture de la soutenabilité de la dette

L'aide publique au développement et les investissements directs étrangers en Afrique sont-ils complémentaires?

L'économie du don chez François Perroux. Actualité et pertinence du modèle perroussien d'aide publique au développement pour le troisième millénaire

Le financement international du développement durable.

La mobilisation contre les changements climatiques

La coordination des politiques budgétaires dans une union monétaire. L'expérience récente des pays de la CEMAC

Vers une typologie des « processus » régionaux.

Le cas de l'Asie orientale

Les capacités d'usage des technologies de l'information et de la communication dans les économies émergentes

Rédaction et administration : Institut d'Étude du Développement Économique et Social

45 bis, av. de la Belle Gabrielle 94736 Nogent sur Marne Cedex

Tél : 0143947226 - fax: 0143947244 - tiermond@univ-paris1.fr

Abonnements et ventes : Armand Colin - www.armand-colin.com/revues.php -

11-15 rue Pierre Rigaud, 94207 Ivry sur Seine cedex -Tel : 0820065 095-fax 0140648951

Armand

Publié avec le concours du Centre national du livre - Prix du numéro : $20 €$

Colin

Abonnements pour l'année 2007 : Particuliers :France $59 \epsilon$-Étranger $69 \epsilon$-Institutions : France $89 \epsilon$ - Étranger $99 \epsilon$ 